\title{
PROTIST DISTRIBUTION IN THE WESTERN FRAM STRAIT IN SUMMER 2010 BASED ON 454-PYROSEQUENCING OF $18 S$ RDNA $^{1}$
}

\author{
Estelle Kilias, ${ }^{2}$ Christian Wolf, Eva-Maria Nöthig \\ Alfred Wegener Institute for Polar and Marine Research, Bioscience, Bremerhaven 27570, Germany
}

Ilka Peeken

Alfred Wegener Institute for Polar and Marine Research, Bioscience, Bremerhaven 27570, Germany MARUM - Center for Marine Environmental Science, Bremen 28359, Germany

and Katja Metfies

Alfred Wegener Institute for Polar and Marine Research, Bioscience, Bremerhaven 27570, Germany

In this study, we present the first comprehensive analyses of the diversity and distribution of marine protist (micro-, nano-, and picoeukaryotes) in the Western Fram Strait, using 454-pyrosequencing and high-pressure liquid chromatography (HPLC) at five stations in summer 2010. Three stations (T1; T5; T7) were influenced by Polar Water, characterized by cold water with lower salinity $(<33)$ and different extents of ice concentrations. Atlantic Water influenced the other two stations (T6; T9). While T6 was located in the mixed water zone characterized by cold water with intermediate salinity $(\sim 33)$ and high ice concentrations, T9 was located in warm water with high salinity $(\sim 35)$ and no ice-coverage at all. General trends in community structure according to prevailing environmental settings, observed with both methods, coincided well. At two stations, $\mathrm{T} 1$ and $\mathrm{T} 7$, characterized by lower ice concentrations, diatoms (Fragilariopsis sp., Porosira sp., Thalassiosira spp.) dominated the protist community. The third station (T5) was ice-covered, but has been ice-free for $\sim 4$ weeks prior to sampling. At this station, dinoflagellates (Dinophyceae 1, Woloszynskia sp. and Gyrodinium sp.) were dominant, reflecting a post-bloom situation. At station $\mathrm{T} 6$ and T9, the protist communities consisted mainly of picoeukaryotes, e.g., Micromonas spp. Based on our results, 454pyrosequencing has proven to be an adequate tool to provide comprehensive information on the composition of protist communities. Furthermore, this study suggests that a snap-shot of a few, but well-chosen samples can provide an overview of community structure patterns and succession in a dynamic marine environment.

Key index words: 454-pyrosequencing; ARISA; Biogeography; Genetic diversity; HPLC; Phytoplankton

\footnotetext{
${ }^{1}$ Received 4 November 2012. Accepted 20 July 2013.

${ }^{2}$ Author for correspondence: e-mail: Estelle.Kilias@awi.de

Editorial Responsibility: T. Mock (Associate Editor)
}

List of abbreviations: Bp, base-pair; CTD, conductivity temperature depth; dNTP, deoxyribonucleoside triphosphate; HPLC, High-Performance Liquid Chromatography; MODIS, Moderate Resolution Imaging Spectroradiometer; OTU, operational taxonomic unit; POC, particulate organic carbon

Global warming is transforming ecosystems on an extraordinary scale. Changes in the Arctic are more intense than in other regions of the world oceans (IPCC, Intergovernmental Panel on Climate Change. Working Group I 2007). The ongoing environmental change requires evaluation of its impact on pelagic ecosystems. These impacts could include species invasions into new areas with more tolerable abiotic conditions, intermingling of formerly nonoverlapping species or the loss of genetic diversity, particularly within local endemics (Cotterill et al. 2008). All these events have in common that they cause changes of biodiversity and thus affect the marine ecosystems, as well as biogeochemical cycling in the Arctic (Wassmann et al. 2011).

Marine phytoplankton is the base of the pelagic food web and a major contributor to the global carbon cycle. The taxonomic composition as well as the biomass of phytoplankton influences the Arctic marine food web, including the trophic interactions and the fluxes of essential nutrients into the euphotic zone (Falkowski et al. 1998, Wassmann et al. 2011). Protists occur in a broad size spectrum ranging from single cells with a size $\sim 0.8 \mu \mathrm{m}$ (Courties et al. 1994) to long chains of cells with sizes $>200 \mu \mathrm{m}$. The size distribution has a big influence on the pelagic food web structure and has the potential to affect the rate of POC export to deep water (Legendre and Le Fèvre 1991, Moran et al. 2012). In order to evaluate consequences of environmental change at the base of the Arctic food web, it is necessary to gain information on the temporal dynamics of phytoplankton compositions and their variability in relation to 
changing environmental conditions (Wassmann et al. 2011).

Until now, studies have focused on either the microplankton fraction (Booth and Horner 1997, Tremblay et al. 2006, Hegseth and Sundfjord 2008), or on the small size fraction, e.g., nano- and picoplankton (Diez et al. 2001, Lopez-Garcia et al. 2001, Moon-van der Staay et al. 2001, Lovejoy et al. 2006, 2007). To our knowledge, studies that cover the entire size classes are scarce in the Arctic. However, information on whole protist community structures is essential to evaluate because all size classes contribute to the functioning of marine ecosystem. Variations in the phytoplankton size structure showed a trend toward smaller cell sizes, which is coupled with rising temperatures (temperature size rule) and decreasing surface nutrient concentrations (stratification-based; Atkinson et al. 2003, Bopp et al. 2005, Daufresne et al. 2009, Moran et al. 2010, Peter and Sommer 2012). Time series studies of satellite derived chlorophyll a concentrations (1997-2009) observed a temporal shift in phytoplankton succession to earlier diatom blooms (Kahru et al. 2011), implying a shift in the succession of size fractions as well. A seasonal shift in protist community, from a diatom to a flagellate-based system, was further observed during receding ice concentrations (Moran et al. 2012). Changes in the cell size dimensions and timing suggest a high relevance to include all size fractions in phytoplankton studies.

In the past, a considerable number of marine surveys took advantage on ribosomal sequence information, which contributed to broaden our understanding of phytoplankton diversity and community structure, including all size fractions (Medlin et al. 2006, Not et al. 2008). Automated ribosomal intergenic spacer analysis (ARISA) is a molecular, cost-effective fingerprinting method, targeting the ribosomal operon and suitable for quick comparative analyses of microbial communities (Danovaro et al. 2006). ARISA is based on analyzing the size of intergenic spacer regions of the ribosomal operon. So far, ARISA has been mainly used for prokaryote diversity studies (Smith et al. 2010) but recently, the method has also been proven to be a valuable tool to assess differences in the structure of marine protist communities (Wolf et al. 2013). However, it is not suited to provide information on the protist community composition. 454-pyrosequencing is suited to provide that kind of information. The high throughput approach allows assessing microbial communities with high resolution based on sufficient deep taxon sampling (Margulies et al. 2005, Stoeck et al. 2010). The application of 454-pyrosequencing in protist diversity surveys revealed a huge hidden diversity and allowed the analysis of rare species (Sogin et al. 2006, Cheung et al. 2010, Stoeck et al. 2010). 454-pyrosequencing was used in this study to take advantage of the mentioned benefits and thus, to provide comprehensive information on the protist diversity, including the micro-, nano-, and picoplankton. The data complement information on the distribution of main autotrophic phyla, derived from HPLC data, obtained by the CHEMTAX ${ }^{\circledR}$ program (Mackey et al. 1996, Higgins et al. 2011).

The Fram Strait presents an excellent observation area to analyze the variability of marine protist communities in the presence of different abiotic factors, because of the variable hydrographical and sea ice conditions. The hydrography is characterized by the inflow of warm and saline Atlantic Water (AW) via the West-Spitzbergen Current (WSC) and by the outflow of cold and low saline Polar Water (PW) via the East Greenland Current (EGC). A significant amount of the AW recirculates directly in the Fram Strait, partly mixing with the colder water and returning southwards (Rudels et al. 2005).

Considering the sensitivity of the Arctic Ocean to global warming and the expected temporal and possible general shift in protist cell size, this study aims to provide information on the genetic diversity and the distribution of eukaryotic protists in the Fram Strait. By achieving this, the present work also relates the corresponding protist composition to the prevailing environmental conditions for a better understanding of respective impacts on community structures.

\section{MATERIALS AND METHODS}

Sampling area. The sampling was performed during the ARK-XXV/2 expedition aboard the RV Polarstern in July 2010 on a transect navigated from $11^{\circ} 58.362^{\prime}$ to $11^{\circ} 5.09^{\prime} \mathrm{E}$ longitude at $\sim 78^{\circ} 50^{\prime} \mathrm{N}$ latitude (Fig. 1). Water samples were taken in the euphotic zone by collecting seawater with $12 \mathrm{~L}$ Niskin bottles deployed on a rosette, equipped with CTD (conductivity, temperature and depth) sensors (Table S1 in the Supporting Information). Temperature and salinity were used from the sensor measurements, while the sea ice condition was determined by visual observation. In total, 16 samples were taken in the upper $50 \mathrm{~m}$ water depth at the chlorophyll maximum (exception: T1). All samples were used for the ARISA and a selection of five samples for further molecular and pigment analysis. For subsequent filtration, $2 \mathrm{~L}$ water subsamples were transferred into polycarbonate bottles. In order to obtain a best possible representation of all cell sizes in the molecular approach, protist cells were collected immediately by fractionated filtration (200 mbar low pressure), through Isopore Membrane Filters (Millipore, Billerica, MA, USA) with pore sizes of 10,3 , and $0.4 \mu \mathrm{m}$. Finally, the filters were transferred into Eppendorf tubes and stored at $-80^{\circ} \mathrm{C}$ until further processing.

Chlorophyll a from satellite data $\mathcal{E}$ filtration in chlorophyll a $\max$. In order to get an impression of the seasonal state of the phytoplankton at the five selected stations (T1, T5, T6, T7, and T9) the area-averaged chlorophyll $a$ concentrations from remote sensing observations of the MODIS were depicted from the month of April through August 2010. The Goddard Earth Science Data and Information Services Center (GES DISC; Acker and Leptoukh 2007) provided the MODIS observations. However, chlorophyll a concentrations from satellite data are limited on the surface water and exclude the chlorophyll $a$ of deeper water layers. For each water 


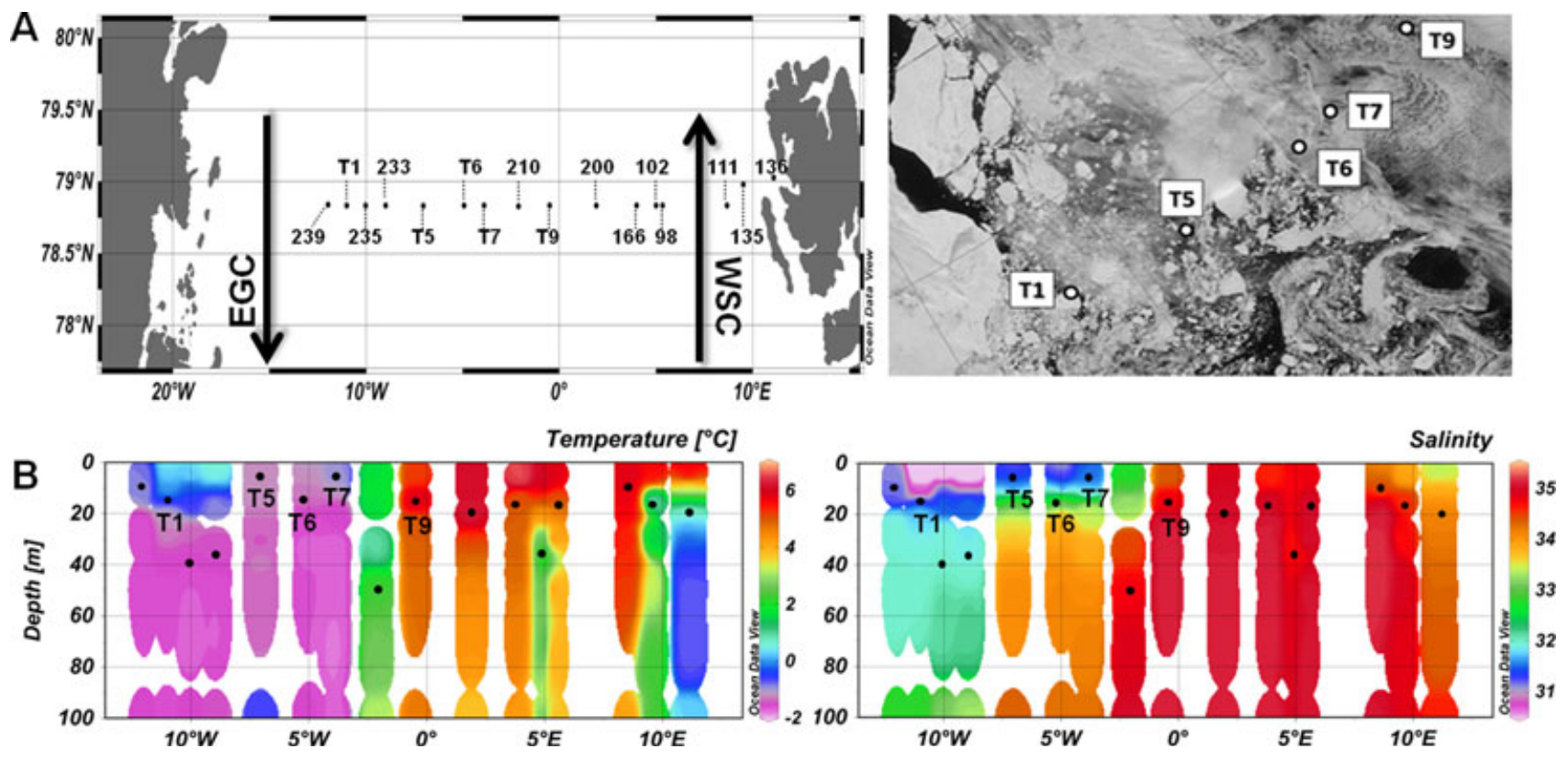

Fig. 1. (A) Map of all stations and ice coverage of 454-pyrosequencing/HPLC stations (MODIS) along the transect running from $11^{\circ} 97 \mathrm{~W}$ to $11.09^{\circ} \mathrm{E}$ longitude and $\sim 78^{\circ} 93^{\prime} \mathrm{N}$ latitude, taken in July 2010 (ARKXXV/2); (B) Temperature $\left({ }^{\circ} \mathrm{C}\right.$ ) and salinity profile of all stations. Water samples have been taken within the chlorophyll maximum layer (exception: T1).

sample, in situ chlorophyll $a$ concentration was analyzed by filtering $0.5-2.0 \mathrm{~L}$ of seawater through Whatman $\mathrm{GF} / \mathrm{F}$ glass fiber filters that were stored at $-20^{\circ} \mathrm{C}$. The filters were extracted in $90 \%$ acetone and analyzed with a Turner-Design fluorometer according to Edler (1979) and Evans and O'Reily (1987). The fluorometer was calibrated with the spectrophotometer. Calibration of the fluorometer was carried out with standard solutions of chlorophyll $a$ (Sigma, Seelze, Germany).

HPLC. For HPLC-pigment analyses, 1-2 L seawater of the same Niskin bottles as used for DNA analysis was filtered on GF/F filters, immediately frozen in liquid nitrogen, and stored at $-80^{\circ} \mathrm{C}$ until further analysis in the laboratory. The pigment analysis was carried out with a Waters HPLC-system. This system was equipped with an auto sampler (device code 717 plus), a pump (device code 600), a Photodiodearray detector (device code 2996), a fluorescence detector (device code 2475) and finally the EMPOWER software. The filters were homogenized for $20 \mathrm{~s}$ with $50 \mu \mathrm{L}$ internal standard (canthaxanthin), $1.5 \mathrm{~mL}$ acetone, and small glass beads in a Precellys ${ }^{\circledR}$ tissue homogenizer. A centrifugation step was performed in which the supernatant liquid was kept and filtered through a $0.2 \mu \mathrm{m}$ PTFE filter (Rotilabo). An aliquot of $100 \mu \mathrm{L}$ was transferred to the auto sampler $\left(4^{\circ} \mathrm{C}\right)$, and mixed with $1 \mathrm{M}$ ammonium acetate solution (ratio: 1:1). Subsequently, the liquid was injected into the HPLC-system. The analysis of the pigments was conducted by reverse-phase HPLC, by the utilization of a VARIAN Microsorb-MV3 C8 column $(4.6 \times 100 \mathrm{~mm})$, and a HPLC-grade solvent (Merck, Darmstadt Germany). The mixture of solvent A was built up of $70 \%$ methanol and $30 \% 1 \mathrm{M}$ ammonium acetate, whereas solvent B contained $100 \%$ methanol (gradient modified after Barlow et al. 1997). Eluting pigments were detected by absorbance $(440 \mathrm{~nm})$, and fluorescence (Ex: $410 \mathrm{~nm}$; Em: $>600 \mathrm{~nm}$ ). Retention times served to identify the pigments by comparing them with the retention times of pure algal extracts, and pure standards. To assure the identity of each pigment diode, array absorbance spectrum (390-750 nm) were compared with the library from the injected standards.
Pigment concentration was quantified based on the peak areas of external standards. Concentrations of external standards were spectrophotometrically determined using extinction coefficients of Bidigare (1991), and Jeffrey et al. (1997). A normalization of the pigment concentrations to the internal standard (canthaxanthin) was finally achieved to counteract possible bias by volume change and experimental losses. The taxonomic structure of the phytoplankton classes was calculated from marker pigment ratios using the CHEMTAX ${ }^{\circledR}$ program (Mackey et al. 1996). Microscopic examination of representative samples from another study in the Arctic was used to identify the various taxa and to constrain the pigment ratio as suggested by Higgins et al. (2011). The resulting phytoplankton group composition was expressed in chlorophyll $a$ concentrations to determine their relative contribution to the total phytoplankton biomass.

DNA isolation. DNA extraction of each filter was carried out with E.Z.N.A TM SP Plant DNA Kit Dry Specimen Protocol (Omega Bio-Tek, Norcross, GA, USA), following the manufacturer's protocol. Genomic DNA was eluted from the column with $60 \mu \mathrm{L}$ elution buffer. The extracts were stored at $-20^{\circ} \mathrm{C}$ until further processing.

ARISA. Initially, identical DNA volumes of each size class $(10,3$, and $0.4 \mu \mathrm{m})$ of each sample were pooled. The amplification of the eukaryotic ITS1 region from the protist samples was carried out with the fluorescently (dye 6-FAM; 6-Carboxyfluorescein) labeled primer 1528F (GTA GGT GAA CCT GCA GAA GGA TCA; modified after Medlin et al. 1988) and the primer ITS 2 (GCT GCG TTC TTC ATC GAT GC; White et al. 1990). The PCR reaction mixture contained $1 \times$ HotMasterTaq buffer $\mathrm{Mg}^{2+} 2.5 \mathrm{mM}$ (5'Prime, Pittsburgh, PA, USA), $0.4 \mathrm{U}^{\mathrm{H}}$ HotMaster Taq polymerase (5'Prime, USA), $10 \mathrm{mg} \cdot \mathrm{mL}^{-1}$ BSA, $10 \mathrm{mM}$ (each) dNTP (Eppendorf, Wesseling-Berzdorf, Germany), $10 \mu \mathrm{M}$ each Primer, $1 \mu \mathrm{L}$ of template DNA $\left(\sim 20 \mathrm{ng} \cdot \mu \mathrm{L}^{-1}\right)$ in a final volume of $20 \mu \mathrm{L}$. The PCR amplification was carried out in a MasterCycler (Eppendorf) under the following conditions: first an initial denaturation step for $3 \mathrm{~min}$ at $94^{\circ} \mathrm{C}$ succeeded by 35 cycles (denaturation at $94^{\circ} \mathrm{C}$ for $45 \mathrm{~s}$, annealing at $55^{\circ} \mathrm{C}$ for $1 \mathrm{~min}$, 
extension at $72^{\circ} \mathrm{C}$ for $3 \mathrm{~min}$ ) and followed by a final extension at $72^{\circ} \mathrm{C}$ for $10 \mathrm{~min}$. The PCR reaction in the analysis was carried out in triplicate for each of the samples. PCR fragment sizes were determined by capillary electrophoresis with an ABI 310 Prism Genetic Analyzer (Applied Biosystems, Grand Island, NY, USA).

The analysis of the electropherograms was carried out with the GeneMapper v4.0 software (Applied Biosystems). To exclude fragments originating from primers or primer dimers, a threshold of $50 \mathrm{bp}$ for peaks was applied. A binning was carried out in $\mathrm{R}$ ( $\mathrm{R}$ Development Core Team 2008) according to Ramette (2009), to remove possible background noises. The resulting data were converted to a presence/ absence matrix and differences in the phytoplankton community structure represented by differences in the respective ARISA data sets were determined by calculating the Jaccard index with an ordination of 10,000 restarts under the implementation of the $\mathrm{R}$ package Vegan (Oksanen et al. 2011). Multi-dimensional scaling (MDS) plots were computed and possible clusters were identified using the hclust function of the same R package. An ANOSIM was conducted to test the significance of the clustering. A Mantel test (10,000 permutations) was used to test the correlation of the protist community structure distance matrix (Jaccard) and the environmental distance matrix (Euclidean). For the Mantel test, the ade $4 \mathrm{R}$ package was applied (Dray and Dufour 2007). To assess the significance of the single environmental variables, a permutation test was calculated using the envfit function of the vegan R package. Subsequently, a PCA of the protist community and the significant environmental factors distances was performed.

Next-generation sequencing. For subsequent 454-pyrosequencing, the V4 region of the $18 \mathrm{~S}$ rDNA was amplified separately for each size fraction to minimize the bias of overrepresentations of larger cell size protists, that might contain higher ribosomal gene copy numbers. The amplification was done with the primer set 528F (GCG GTA ATT CCA GCT CCA A), and 1055R (ACG GCC ATG CAC CAC CAC CCA T; modified after Elwood et al. 1985). The PCR reaction mixture and the reaction conditions were composed as described previously for ARISA. The resulting PCR products of each size fraction were purified with the Mini Elute PCR Purification Kit (QIAgen, Hamburg, Germany). For subsequent 454-pyrosequencing, equal volumes of the eluted PCR product were pooled. The pooled amplicons were sequenced by GATC Biotech GmbH (Konstanz, Germany) in a 454 GS FLX sequencer (Roche, Mannheim, Germany).

Data analysis of 454-pyrosequencing. In order to increase the quality of the raw sequences, reads shorter than $300 \mathrm{bp}$ were excluded from the analysis to guarantee the analysis of the whole V4 region ( 230 bp; Nickrent and Sargent (1991)). Sequences longer than 670 bp (expected amplicon size) and those with more than one uncertain base $(\mathrm{N})$ were further removed. Chimeric sequences were detected using the chimera-detecting software UCHIME (Edgar et al. 2011), and excluded from analysis. OTUs were generated by clustering the remaining high quality reads using the software package Lasergene Seqman Pro (DNAStar, Madison, WI, USA). A threshold of $97 \%$, and a match size of $50 \mathrm{bp}$ was applied to minimize the danger of overestimating the diversity, and to allow a comparison of the current data set with other published data that used the $97 \%$ similarity threshold (Kunin et al. 2010). All singletons, defined as an OTU composed of one single sequence, i.e., that only occurs once in the whole analysis were removed to evade possible errors induced during the sequencing process. Table 1 shows an overview of the 454-pyrosequencing data processing, presenting the numbers of raw reads, the numbers of unqualified and removed reads and the final read numbers, including the OTU numbers
TABle 1. Summary of the reads quantity during the analysis process.

\begin{tabular}{lrrrrr}
\hline \hline & \multicolumn{1}{c}{$\mathrm{T} 1$} & \multicolumn{1}{c}{$\mathrm{T} 5$} & \multicolumn{1}{c}{$\mathrm{T} 6$} & $\mathrm{~T} 7$ & $\mathrm{~T} 9$ \\
\hline $\begin{array}{l}\text { Raw read } \\
\text { numbers }\end{array}$ & 44,713 & 23,041 & 10,141 & 38,126 & 36,691 \\
$\begin{array}{l}\text { Removal of } \\
\text { quality filtering }\end{array}$ & 33,511 & 5,916 & 4,435 & 26,522 & 13,657 \\
$\begin{array}{l}\text { Final read } \\
\text { numbers }\end{array}$ & 11,202 & 17,125 & 5,706 & 11,604 & 23,034 \\
$\begin{array}{l}\text { OTU } \\
\text { (threshold: 97\%) }\end{array}$ & 526 & 795 & 531 & 745 & 1,108 \\
\hline
\end{tabular}

after clustering. Consensus sequences of the OTUs were used in order to reduce possible sequencing errors and placed into a reference tree build up by a selection of 1,200 highquality sequences from the SILVA reference database (SSU Ref 108), containing representatives of all main eukaryotic phyla. This involved the use of the pplacer software (Matsen et al. 2010). Sequences that affiliated with non-protist phyla in the tree were excluded from further analyses. With the pplacer software, it is possible to quantify the likelihood of the read-placement in the phylogenetic tree. This information provides an estimate of the reliability of the annotation. In this study, we used a threshold of $99 \%$ for the annotation of the sequence reads. This strict threshold determines the taxonomic level at which a sequence read can be annotated. It is only possible to annotate a sequence with high taxonomic resolution, if a reference sequence is available, which is very often not the case. Thus, many sequences can only be reliably annotated at higher taxonomic levels.

Statistics-HPLC and 454-pyrosequencing. To compare the HPLC data with the 454-pyrosequencing reads, distances between the samples were computed in $\mathrm{R}$ by using the Bray Curtis index for the HPLC data and the Jaccard index for the 454-pyrosequencing data under the use of the package vegan (Oksanen et al. 2011). Possible clusters were screened with the hclust function and the significance of the clustering was tested with an ANOSIM. The calculated distances of the HPLC and 454-pyrosequencing samples were transferred in MDS plots and the correlation between both distance matrices was tested with a Mantel test in the $\mathrm{R}$ package ade4 (Dray and Dufour 2007).

\section{RESULTS}

Environmental characteristics. The investigated transect in the Western Fram Strait was located in a hydrodynamic zone composed of two major water masses that could be designated oceanographically (temperature and salinity) as the warm WSC in the east and the cold EGC in the west (Fig. 1A). In the western section of the transect (St.239 to T7), the temperatures were around the freezing point ranging from $-1.5^{\circ} \mathrm{C}$ to $0.7^{\circ} \mathrm{C}$. In the more eastern section of the transect (St.210 to St.136), the temperatures were higher and ranged between $4.1^{\circ} \mathrm{C}$ and $6.2^{\circ} \mathrm{C}$. Salinity was lowest in the western section of the transect (30.7-32.8) and increased toward east (Fig. 1B). The ice conditions during the sampling period were not evenly distributed along the transect. Sea ice was just observed in the western part (239 to T7). In this region, a large polynya with 
patchy ice coverage stretched out along the East Greenland coastline. This influenced in particular four sampling sites (T1 to T5) and resulted in variable ice coverages. Regarding the selected samples, the highest ice concentration was observed at T6 $(80 \%)$ and declined toward the west (T5: $40 \%$, T1: $30 \%$; Fig. 1A). In contrast, station $\mathrm{T} 7$ and $\mathrm{T} 9$ were virtually not ice covered. However, while $\mathrm{T} 7$ was directly located at the ice edge $(20 \%)$ and thus still affected by the prevailing ice cover, T9 was located in moderate distance and served as an example for a sampling site located in the open ocean with no ice coverage at all. Based on the salinity and temperature profile, we suggest two possible hydrographic classifications of the sampling sites. One grouping locates St.239-St.233 (including T1) in the PW of the EGC, T5-T7 in a mixing zone, and the following stations (including T9) in the AW of the WSC. This grouping considers a possible influence of melt water at $\mathrm{T} 5$ and $\mathrm{T} 7$, resulting in a salinity decrease at both stations compared to T6. Another possible grouping, locates stations 239 to $\mathrm{T} 5$ and $\mathrm{T} 7$ in the PW of the EGC, and T6, together with the stations T9 to St.136 in the AW of the WSC. This grouping considers a possible influence of the recirculation branch of the WSC at T6.

Chlorophyll a biomass (all stations). The area-averaged chlorophyll a concentrations obtained by remote sensing observations showed similar values over the selected stations of the transect ranging around $\sim 0.4 \mathrm{mg} \cdot \mathrm{m}^{-3}$ within our investigation period in July. During the entire growth period in the area of the transect, a peak in biomass (chlorophyll $a>1.5 \mathrm{mg} \cdot \mathrm{m}^{-3}$ ) was observed in June at the more eastern stations $\mathrm{T} 6$ and $\mathrm{T} 9\left(5^{\circ} \mathrm{W}-0^{\circ} \mathrm{E}\right)$. At the western stations, the chlorophyll $a$ values remained low throughout the whole growth season with an almost linear increase from April to August 2010 (Fig. S1 in the Supporting Information). Chlorophyll $a$ biomass in the chlorophyll $a$ maxima at the 16 stations showed similar concentrations ranging from $\sim 0.3$ to $1.7 \mathrm{mg} \cdot \mathrm{m}^{-3}$ (Table S1).

ARISA (all stations): The analysis of the ITS1 length heterogeneity of the 16 stations resulted in 252 different PCR-fragments amplified from the ribosomal ITS region of 50-496 bp length. Along the transect, the fragment number per sample ranged between 70 and 113. The minimum number of PCR-fragments was found at stations 239 and T6 and the maximum number at station 210. Based on Jaccard's distances the ARISA profiles grouped into three significantly distinct clusters in a metaMDSplot (Fig. 2). Community profiles within a cluster are more similar to each other than to community profiles of other clusters. The clustering is supported by an ANOSIM $(R=1, P=0.001)$. The biggest cluster was composed of eight samples, including $\mathrm{T} 9$, that were all located in the eastern part of the transect, the WSC. A second cluster was composed of three stations (T5, T6, and T7), origi-

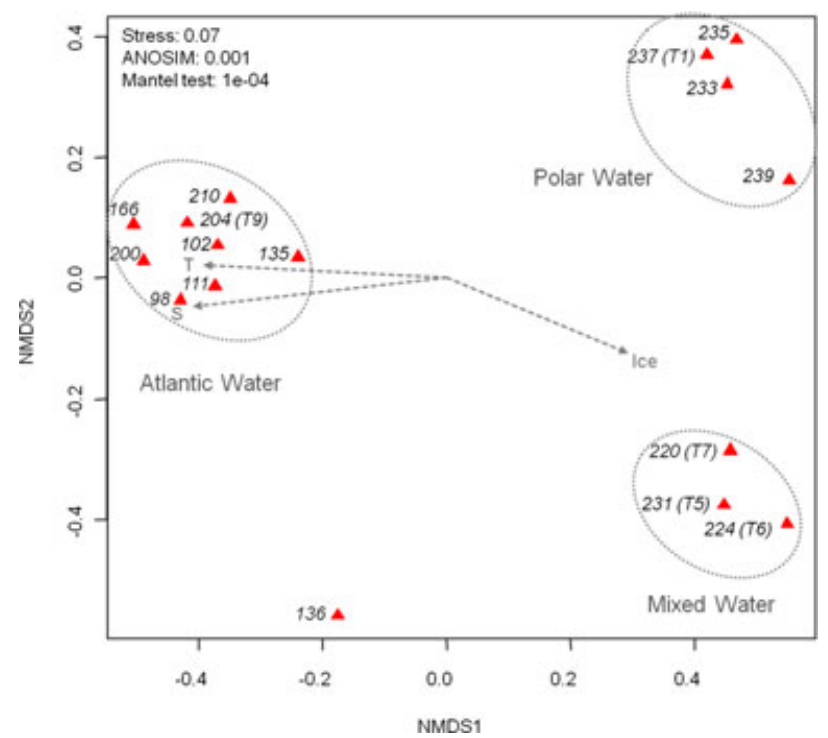

FIG. 2. Automated Ribosomal Intergenic Spacer Analysis MDS plot of all 16 samples and their clustering according to the environmental factors ( $\mathrm{T}, \mathrm{S}$, and ice concentration). Protist community structure distance matrix was computed by the Jaccard index while Euclidean distances were calculated for the environmental parameters.

nating from the mixed water zone between the WSC and the EGC, while a third cluster contained the four remaining samples (including T1), originating from the EGC. The outlier sample (St. 136) was collected close to the Svalbard coastline. Distances of the ARISA profiles are significantly correlated with the ones of the environmental factors ( $\mathrm{T}, \mathrm{S}$, and ice), computed by the Euclidean-index (Mantel test: $r=0.76, P=1 \mathrm{e}^{-04}$ ). Temperature and salinity presented a higher significance $(P=0.001)$ than ice coverage $(P=0.017)$. The PCA of both profiles reveals that samples from the eastern part (WSC) are primarily separated from the other clusters (middle and western section) by higher temperature and salinity, but lower ice coverages. A separation of the middle and western part clusters was not based on the investigated environmental parameters.

According to the clustering in the MDS-plot and the prevailing water masses, we chose five samples as subjects for a more detailed analysis of the protist composition based on HPLC and 454 pyrosequencing.

HPLC (five stations). The results of the HPLC analyses are presented in Figure 3A. To facilitate a comparison with the 454-pyrosequencing reads, the HPLC data set was adjusted by removing the chlorophyll $a$ values of cyanobacteria. The residual pigment patterns were used to identify main protist divisions such as haptophytes, chlorophytes, cryptophytes, stramenopiles (diatoms and chrysophytes), and alveolates (dinoflagellates). Protist groups such as dinoflagellates and ciliates can acquire phototrophy by algae 
A
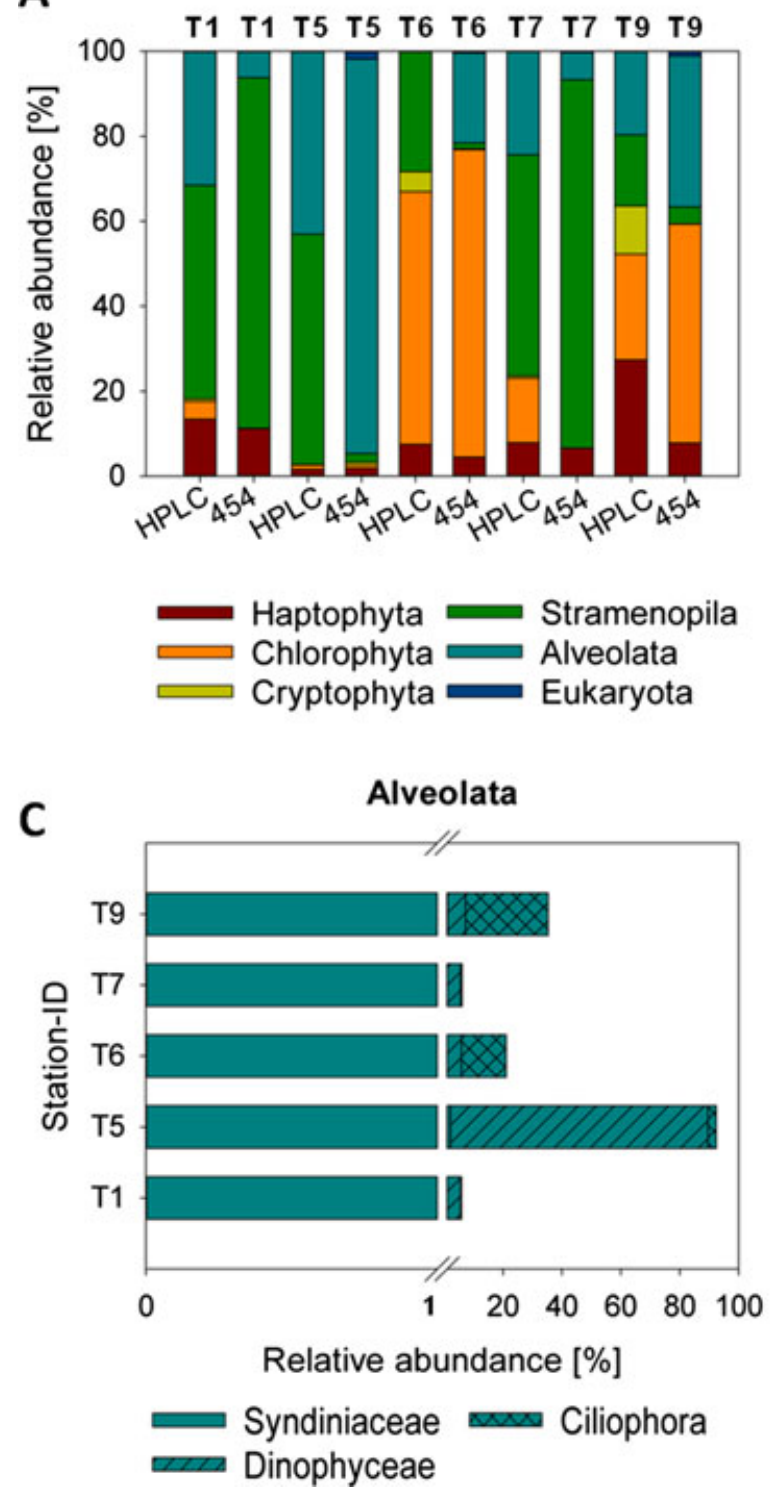

B
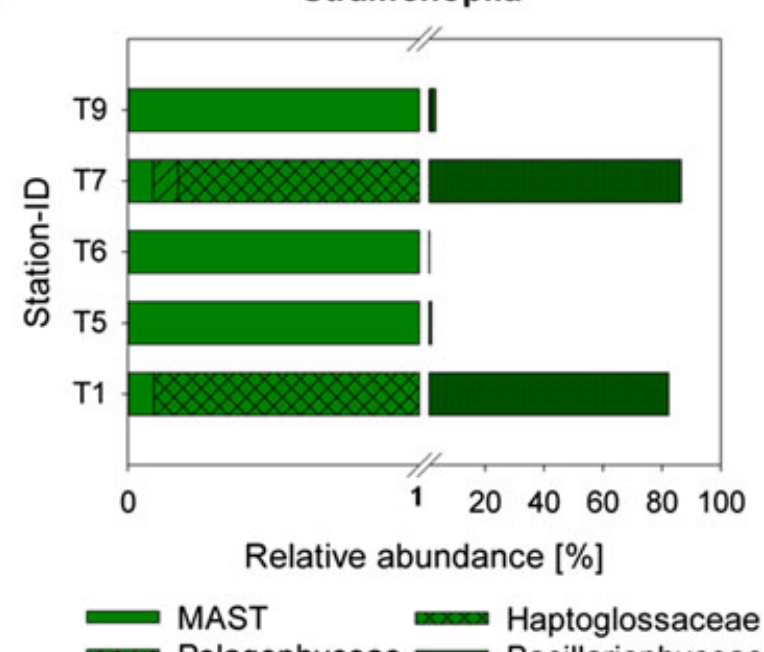

Pelagophyceae Bacillariophyceae

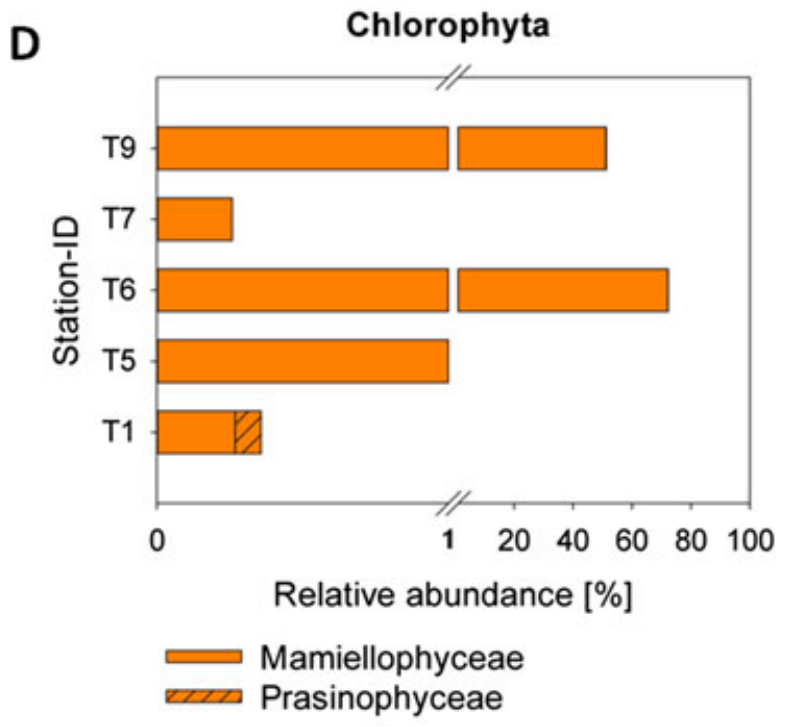

Fig. 3. Relative abundance of the major taxonomic groups along the selected sampling sites (T1, T5, T6, T7, and T9). (A) Comparison of the HPLC (phytoplankton) and 454-pyrosequencing (protist) data set. (B-D) Higher taxonomical resolution of the 454-pyrosequencing reads for: Stramenopila (B), Alveolata (C) and Chlorophyta (D).

endosymbiosis or plastid retention and hence contribute to the pigment data (Stoecker et al. 2009).

In summary, the majority of the samples was dominated by stramenopiles, alveolates and chlorophytes, whereas cryptophytes contributed less to the phytoplankton community, never exceeding $11 \%$ (T9). The relative contribution of the three dominating groups to the phytoplankton community varied at the different sampling sites. Stramenopiles accounted for up to the half of the autotrophic assemblage at station $\mathrm{T} 1 \quad(50 \%), \mathrm{T} 5 \mathrm{(54 \% )}$, and T7 (52\%), whereas they accounted for a lesser extent to the protist assemblages at the other two stations. With the exception of station T6, alveolates were observed with a proportion of $20 \%-43 \%$ at all remaining sampling sites. The highest contribution of alveolates was observed at the western stations T5 (43\%) and T1 (32\%). Chlorophytes exhibited the lowest proportion, counting for $4 \%$ and $1 \%$ at station $\mathrm{T} 1$ and $\mathrm{T} 5$, respectively. However, they displayed a high contribution at T6 $(59 \%)$ and were strongly represented at T9 $(24 \%)$. To achieve a better insight of the community shifts along the transect, each station was analyzed successively. Starting at the western station, T1, we found a community structure that was dominated by stramenopiles and alveolates, accounting for $82 \%$ of the total community. The residual fraction of $18 \%$ was primarily composed by haptophytes (13\%), and some chlorophytes $(4 \%)$. A similar community structure was 
observed at T5, where stramenopiles and alveolates cumulated abundance up to $97 \%$. At station T6, phytoplankton composition changed. We observed a dominance of chlorophytes $(59 \%)$, a smaller proportion of stramenopiles (28\%), and an absence of alveolates. In comparison to the other stations, cryptophytes $(5 \%)$ and haptophytes $(7 \%)$ accounted for higher percentages in T6; however, the overall contribution remained minor. At T7, one half of the protist community consisted of stramenopiles while the other half was composed by alveolates (24\%), chlorophytes $(15 \%)$, and haptophytes $(8 \%)$. Protist community composition was the most balanced in the open ocean reference station, T9. Haptophytes as well as chlorophytes constituted approximately a quarter of the total assemblage, while alveolates $(20 \%)$, stramenopiles $(18 \%)$, and cryptophytes $(11 \%)$ were sharing the remaining assemblage.

454-pyrosequencing (five stations). The sequencing of the five water samples resulted in 10,141-44,713 raw sequences. Quality filtering, including chimera check and removal of short reads $(<300 \mathrm{bp})$, reduced the number of reads to 5,706 (T6)-23,034 (T9) quality checked sequences (Table 1). Subsequent clustering of the quality checked sequences resulted in 526 OTUs (T1)-1,108 OTUs (T9). The OTUs were composed on one hand of few OTUs that were represented by many reads (abundant taxa), and on the other hand of many OTUs that were represented by just a few reads (rare taxa). Abundant taxa accounted for $\geq 1 \%$ (abundant biosphere) of the protist assemblage, while rare taxa accounted for $<1 \%$ (rare biosphere). The distribution of the OTUs is provided as supplement in the annex (Table S2 in the Supporting Information). The number of non-protist sequences varied strongly between the samples, showing a minimum number of $\sim 27$ sequences $(<1 \%)$ at $\mathrm{T} 5$ and $\mathrm{T} 6$, a moderate number of 861 sequences $(\sim 2 \%)$ at T9 and a maximum number of $\sim 11,524$ at $\mathrm{T} 1$ and T7 $(\sim 25 \%-30 \%)$. The remaining reads were aligned with the SILVA aligner (Pruesse et al. 2007), and placed into the ARB reference database tree (complete SSU Ref 108) containing around 50,000 eukaryotic sequences (Ludwig et al. 2004).

The relative contribution of the major protist groups (same taxonomic level as for the pigment data) was dominated by stramenopiles, alveolates and chlorophytes, as indicated previously by the HPLC (Figs. 3A and 4). Stramenopiles accounted for $\sim 85 \%$ of the protist community in $\mathrm{T} 1$ and $\mathrm{T} 7$, while the relative abundance at the residual stations was minor $\sim 2.5 \%$. The higher taxonomical resolution of the group (Fig. 3B) revealed that the majority of sequences affiliated to bacillariophytes (diatoms). Phylotypes of Haptoglossa accounted for $<1 \%$ at station $\mathrm{T} 1$ and $\mathrm{T} 7$, while marine stramenopiles (MAST) were mainly represented at $\mathrm{T} 5$ and $\mathrm{T} 9(\sim 0.8 \%)$ and pelagophytes at T6 and T9 $(0.3 \%)$. The contribution of alveolates was highest at station T5 with $\sim 93 \%$,
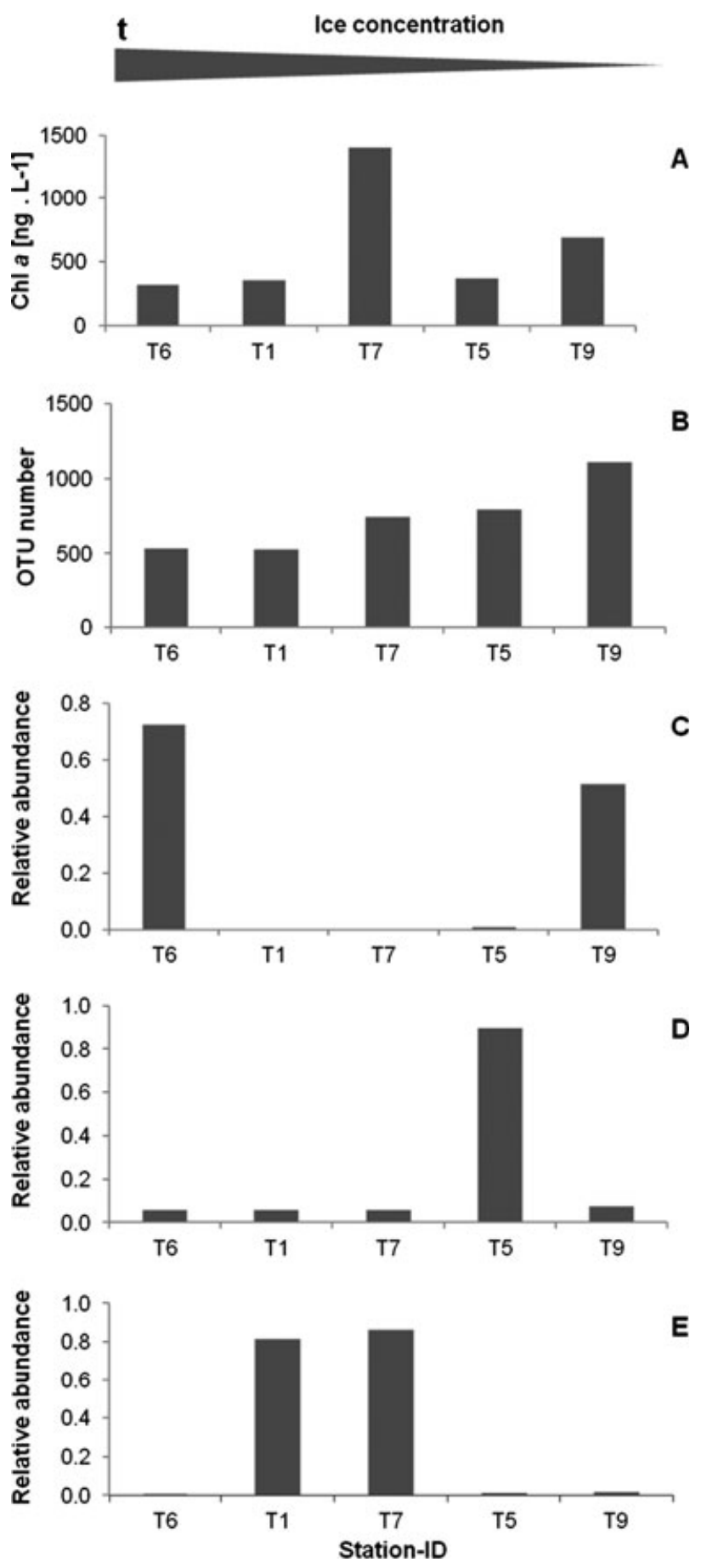

FIG. 4. Biomass, species richness (OTU number), and main protist groups along the decreasing ice concentration. (A) biomass (chlorophyll $a$ : Chl $a \mathrm{ng} \cdot \mathrm{L}^{-1}$, (B) species richness (OTU number), (C) chlororphytes, (D) dinophytes and (E) diatoms. $\mathrm{T} 1, \mathrm{~T} 5$, and $\mathrm{T} 7$ are influenced by the cold and less saline Polar Water of the East Greenland Current, T6 and T9 are influenced by the warmer and saltier Atlantic water of the West Spitzbergen Current recirculation branch.

moderate at T6 $(21 \%)$ and T9 $(36 \%)$ and lowest at $\mathrm{T} 1$ and $\mathrm{T} 7$ (both $\sim 6 \%$ ). Alveolates were further subdivided by 454 -pyrosequencing in ciliate, dinophyte, 
and syndiniales phylotypes (Fig. 3C). Except of station $\mathrm{T} 6$ and T9, dinophytes dominated the relative abundance within alveolates. In particular, station T5 showed a high proportion of $87.4 \%$, while the contribution in the residual stations varied between $5.4 \%$ and $6.2 \%$. Ciliates dominated the stations T6 $(15 \%)$ and T9 $(28 \%)$ and further displayed a high abundance at T5 $(2.9 \%)$. Phylotypes of the family Syndiniaceae generally accounted for smaller proportions and were just observed in higher relative abundances at T5 $(2.2 \%)$ and T9 $(1.2 \%)$. Chlorophytes presented the highest shares at station T6 $(\sim 72 \%)$ and T9 $(52 \%)$ and contributed to less than $1 \%$ at the remaining stations. The group was almost exclusively consistent of mamiellophytes (Fig. 3D). Protist community shifts were more distinct in the 454-pyrosequencing data than in the HPLC data. In the western station (T1), a very high dominance of stramenopiles and smaller shares of haptophytes $(11 \%)$ and alveolates $(6 \%)$ characterized the protist community. In contrast, T5 presented an assemblage that was almost completely dominated by alveolates. T6 presented a more balanced community structure. The station was dominated by chlorophytes $(72 \%)$ but alveolates $(21 \%)$ and haptophytes $(5 \%)$ further contributed to higher percentages. The community structure at station T7 showed again a stramenopile dominated assemblage with low shares of haptophytes $(7 \%)$ and alveolates $(6 \%)$. At the most eastern station (T9), one half of the community was consistent of chlorophytes, while the other half was mainly represented by alveolates (36\%) and some haptophytes $(8 \%)$ and stramenopiles $(4 \%)$.

The qualitative species composition of the abundant biosphere is presented in Table 2. T1 and T7 showed a similar qualitative species distribution, but differed in the quantitative composition of the protist communities. The portion of Phaeocystis sp. (haptophyte) and Porosira sp. (bacillariophyte) was 2-fold higher at T1 than at T7. The genus Thalassiosira (bacillariophyte) was most abundant in both stations and represented by four different phylotypes: Thalassiosira sp.1 dominated at T1 (23\%), but accounted for $7 \%$ of the reads at station T7. Thalassiosira sp.3 was most abundant at T7 (10\%) with similar percentage at $\mathrm{T} 1(9 \%)$. The contribution of Gyrodinium sp. (dinophyte) was also similar at T1 (3\%) and T7 (2\%). In contrast, Fragilariopsis sp. (bacillariophyte) was present in the abundant biosphere of $\mathrm{T} 1(3 \%)$, but contributed to the rare biosphere at $\mathrm{T} 7(<1 \%)$.

The abundant biosphere of T6 and T9 was also similar and coincided in the presence and absence of phylotypes. In this respect, both stations were dominated by chlorophytes that were represented by two phylotypes of the genus Micromonas (mamiellophyte), and one of the genus Bathycoccus (prasinophytes). Bathycoccus sp. was in both stations a minor contributor $(\sim 2 \%)$, while Micromonas accounted for $57 \%$ (T6) and $41 \%$ (T9) of the sequence reads. One phylotype, Micromonas sp. 1, contributed $90 \%$ of the total OTUs, while the other one, Micromonas sp. 2, made only a small contribution to the protist assemblage. Phaeocystis sp. accounted for similar proportion of the protist community as previously observed at $\mathrm{T} 1$ and $\mathrm{T} 7$ and accounted for $3 \%$ in $\mathrm{T} 6$ and $6 \%$ in $\mathrm{T} 9$, respectively. OTUs assigned to dinoflagellates made only a minor contribution to the protist community at T6 $(2 \%)$ and T9 (3\%). Stramenopiles, e.g., diatoms, were neither present in the abundant biosphere in $\mathrm{T} 6$ nor present in T9. Ciliates contributed to the abundant community in T9, but just one phylotype was shared with T6 (Ciliophora 1; 3\%).

Station T5 presented a different picture of the protist community. The abundant biosphere showed no occurrence of haptophytes, chlorophytes, stramenopiles, or ciliates and was constituted exclusively by dinoflagellates. Dinoflagellates were represented by five different phylotypes accounting for $74 \%$ of the total reads. Two phylotypes, Dinophyceae 1 (dinophyte) and Woloszynskia sp. (dinophyte), contributed a higher proportion ( $32 \%$ and $27 \%$, respectively) of the total read abundance, while the residual phylotypes accounted for $1 \%-9 \%$. The majority of phylotypes that were abundant in one of the stations could at least be found within the rare biosphere of one of the other stations. Exceptions were mainly restricted to station $\mathrm{T} 7$ and $\mathrm{T} 1$.

Comparison of HPLC and 454-pyrosequencing. The comparison of both methods showed a high similarity which is shown on the one hand in the clustering of the samples in the HPLC and 454pyrosequencing approach and on the other hand, in the ordination of the distances in the MDS-plots (data not shown). Both approaches referred to three separate clusters where $\mathrm{T} 1$ and $\mathrm{T} 7, \mathrm{~T} 6$ and T9, and T5 grouped together. The implementation of the ANOSIM test confirmed the differences between the separate clusters for the 454-pyrosequencing ( $P$-value: 0.05 ) and suggested differences between the clusters for the HPLC ( $P$-value: 0.068$)$. The correlation of both data sets was tested with a Mantel test and showed a high significance $(P$-value: $0.04)$.

\section{DISCUSSION}

This study aimed at investigating protist assemblages in the physically complex environment of the Western Fram Strait based on HPLC and deep taxon sampling of 454-pyrosequencing. These data can contribute to establishing baseline information for future investigations in the fast changing Arctic Ocean. Prior to an interpretation of our results in the light of the respective environmental conditions, we start the discussion with a comparison between the 454-pyrosequencing and the HPLC data. On the one hand, we analyzed our samples with both techniques to prove the significance of using molecular 
TABLE 2. Summary of the phylotypes obtained by 454-pyrosequencing and representing the abundant biosphere ( $\geq 1 \%)$ in at least one station, $r$ refers to the occurrence of the phylotype in the rare biosphere $(<1 \%)$.

\begin{tabular}{|c|c|c|c|c|c|c|}
\hline Class & Phylotype & $\mathrm{T} 1[\%]$ & T5 [\%] & $\mathrm{T} 6[\%]$ & $\mathrm{T} 7[\%]$ & T9 [\%] \\
\hline Haptophyte & Phaeocystis sp. & 10.5 & $\mathrm{r}$ & 2.8 & 4.3 & 5.8 \\
\hline Mamiellophyte & Micromonas sp. 1 & $\mathrm{r}$ & $\mathrm{r}$ & 51.5 & $\mathrm{r}$ & 37.7 \\
\hline Mamiellophyte & Micromonas sp. 2 & $\mathrm{r}$ & $\mathrm{r}$ & 5.2 & - & 3.6 \\
\hline Prasinophyte & Bathycoccus sp. & - & $\mathrm{r}$ & 2.1 & - & 1.8 \\
\hline Bacillariophyte & Porosira sp. & 11.1 & $\mathrm{r}$ & $\mathrm{r}$ & 6.4 & $\mathrm{r}$ \\
\hline Bacillariophyte & Thalassiosira sp. 1 & 23.2 & $\mathrm{r}$ & $\mathrm{r}$ & 7.1 & $\mathrm{r}$ \\
\hline Bacillariophyte & Thalassiosira sp. 2 & 10.1 & $\mathrm{r}$ & $\mathrm{r}$ & 5.8 & $\mathrm{r}$ \\
\hline Bacillariophyte & Thalassiosira sp. 3 & 8.8 & $\mathrm{r}$ & $\mathrm{r}$ & 9.8 & $\mathrm{r}$ \\
\hline Bacillariophyte & Thalassiosira sp. 4 & 1.7 & $\mathrm{r}$ & $\mathrm{r}$ & 1.1 & $\mathrm{r}$ \\
\hline Bacillariophyte & Fragilariopsis sp. & 2.5 & $\mathrm{r}$ & - & $\mathrm{r}$ & $\mathrm{r}$ \\
\hline Dinophyte & Gyrodinium sp. & 2.9 & 8.8 & $\mathrm{r}$ & 2.1 & 1.5 \\
\hline Dinophyte & Woloszynskia sp. & $\mathrm{r}$ & 27.1 & $\mathrm{r}$ & $\mathrm{r}$ & $\mathrm{r}$ \\
\hline Dinophyte & Dinophyceae 1 & $\mathrm{r}$ & 32.2 & 1.8 & $\mathrm{r}$ & 2.6 \\
\hline Dinophyte & Dinophyceae 3 & $\mathrm{r}$ & 5.0 & $\mathrm{r}$ & $\mathrm{r}$ & $\mathrm{r}$ \\
\hline Dinophyte & Symbiodinium sp. & $\mathrm{r}$ & 1.1 & $\mathrm{r}$ & $\mathrm{r}$ & - \\
\hline Ciliate & Ciliophora 1 & $\mathrm{r}$ & $\mathrm{r}$ & 2.6 & - & 2.1 \\
\hline Ciliate & Ciliophora 2 & $\mathrm{r}$ & $\mathrm{r}$ & $\mathrm{r}$ & $\mathrm{r}$ & 3.6 \\
\hline Ciliate & Ciliophora 3 & $\mathrm{r}$ & $\mathrm{r}$ & $\mathrm{r}$ & $\mathrm{r}$ & 2.6 \\
\hline Ciliate & Ciliophora 4 & - & $\mathrm{r}$ & $\mathrm{r}$ & $\mathrm{r}$ & 4.3 \\
\hline
\end{tabular}

tools in polar plankton ecology and, on the other hand, to point out some strengths and weaknesses for the use of both methods, in combination, for assessments of plankton ecology.

454-pyrosequencing and HPLC. In the last years, nucleic acid based screening tools have experienced a rapid development, enabling deep taxon sequencing, which allowed the consideration of the rare biosphere (Sogin et al. 2006). In this publication, 454-pyrosequencing was applied to analyze the genetic diversity of the whole protist size spectrum in the Western Fram Strait, while HPLC was used as an evaluation of the 454-pyrosequencing results. To our knowledge, an evaluation of 454-pyrosequencing data with an established pigment-based method like HPLC has not been done so far. Both methods have in common that they include the whole size spectrum of marine protists in the analyses. Therefore, HPLC has the potential to be an appropriate method to evaluate 454-pyrosequencing data. However, it has to be considered that the different methods rely on different markers, the $18 \mathrm{~S}$ rDNA gene (Vaulot et al. 2008) and photosynthetic pigments (Wright et al. 1991), respectively. Thus, 454-pyrosequencing is detecting all, autotrophic, mixotrophic, and heterotrophic protists, while the detection of protists with HPLC is restricted to autotrophic and mixotrophic cells. Moreover, 454-pyrosequencing and HPLC differ in the taxonomic resolution of the protist community with higher resolutions in the 454-pyrosequencing. Consequently, an appropriate evaluation of 454-pyrosequencing data with HPLC demands the consideration of these methodological differences. In this study, five samples from different locations in the Western Fram Strait were analyzed with both methods. The results of the different methods are in good agreement considering the main protist shifts. In this respect, the con- tribution of haptophytes and chlorophytes to the protist communities at the different sampling sites coincided well. Both taxa include auto- and mixotrophic contributors, in which mixotrophs are often found within the prymnesiophytes (haptophyte; Gonzalez et al. 1993, Liu et al. 2009, Flynn et al. 2013). Thus, HPLC and 454-pyrosequencing detect the same group of species (autotrophs and mixotrophs), and consequently result in similar protist observations. Furthermore, HPLC and 454-pyrosequencing were in strong accordance for cryptophytes. Only two stations (T6 and T9) showed slight elevated numbers in the HPLC data. Main differences between the results of HPLC and 454-pyrosequencing sets were observed for alveolates (dinoflagellates and ciliates) and stramenopiles. In this case, particularly station $\mathrm{T} 1, \mathrm{~T} 5$, and $\mathrm{T} 7$ were affected. In comparison to 454-pyrosequencing, HPLC is overestimating the proportion of alveolates at $\mathrm{T} 1$ and $\mathrm{T} 7$, while the proportion is underestimated at T6. In contrast, stramenopiles are underestimated at $\mathrm{T} 1$ and $\mathrm{T} 7$, while they appear as overestimated at $\mathrm{T} 6$. If the proportions of alveolates and stramenopiles are summed up, HPLC and 454pyrosequencing give similar relative amounts of the two taxa to the protist community.

The relative abundance of alveolates and particularly dinoflagellates is difficult to estimate. Dinoflagellates are an important but physiologically diverse group with a high proportion of heterotrophic species. However, the acquisition of phototrophy, and thus the combination of photo- and heterotrophy (mixotrophy), is widely distributed in dinoflagellates (Stoecker et al. 2009). Most dinoflagellates achieve mixotrophy by the ingestion of phytoplankton and sequestering of the respective plastids/multiple organelles, as for instance all members of the family Gymnodiniaceae (Fields and Rhodes 1991, Skovg- 
aard 1998, Stoecker et al. 2009). Hence, the variability in dinoflagellate nutrition strategies constitutes a problematic issue for the comparison of alveolate proportions in the HPLC and 454-pyrosequencing data set. Ciliates constitute another problematic group for HPLC and 454-pyrosequencing data comparison because of the acquired phototrophy of some marine and freshwater species that were estimated to account for a high share of 23\% (Foissner et al. 1999). The missing of characteristic marker pigments, however, obviates the detection of ciliates in the HPLC. The critical point in retrieving a pigment-based phytoplankton composition is the input ratio of the marker pigments (reviewed in Higgins et al. 2011), where particularly dinoflagellates are underestimated. Indeed, the effect of endosymbionts on pigment signatures of hosting protists may influence the interpretation, as dinoflagellates have been reported with characteristics specific for chrysophytes (Jeffrey et al. 1975), haptophytes (Bjørnland and Liaaen-Jensen 1989), and green algae (Watanabe et al. 1987, 1990). For the observed discrepancy in alveolate proportions in both data sets, we assume that the underestimation at station T6 can be explained by the fact that HPLC excludes heterotrophs, while 454-pyrosequencing detects all kinds of protists. Apart from that, the occurrence of fucoxanthin, a diatom marker pigment, within several dinoflagellates may further lead to an underestimation of dinoflagellates (alveolates) but an overestimation of diatoms (stramenopiles; Irigoien et al. 2004). This explains the variance of alveolate and stramenopile distribution in the data sets but the concurrent similar proportion in the "summing-up" of both groups.

In contrast, the presence of several copies of the rRNA operon that are not identical for the different protist taxa could explain the comparatively underestimation of alveolates at T1 and T7 by 454-pyrosequencing. Bacillariophytes, and especially the genus Thalassiosira, were found to hold a high number of rRNA copies (Zhu et al. 2005). This effect is more essential for the big compared to small-sized cells because the latter have a smaller genome size, and therefore limited rRNA copy numbers (Vaulot et al. 2008). As the cell size plays a critical role, diatoms could be overrepresented in case of the simultaneous presence of small dinoflagellates.

In summary, based on the evaluation of HPLC data with auto- and mixotrophic taxa, 454-pyrosequencing proved to be a reliable molecular tool in polar plankton ecology that facilitates a profound overview of the whole protist assemblage, and a quick compass of community structure shifts, including information on the taxa involved. The higher taxonomic resolution makes 454-pyrosequencing more advantageous compared to HPLC. However, a combination of both methods for ecology studies can provide a rough estimate of photosynthetic active and non-active protist shares within a community.
Protist distribution in the environmental context. Future investigations of climate change consequences on the diversity and distribution of Arctic eukaryotic protist require first, a characterization of the "standing stock" and the respective environmental factors, influencing geographical expansion (Lovejoy et al. 2007, Hamilton et al. 2008). A variety of different approaches are eligible to assess protist compositions. Most of them are based on microscopic analysis. However, common light and epifluorescence microscopic approaches are not well suited for detailed taxonomic characterization of the very small size classes of partly nano- and mainly picoplankton. The latter organisms are too small to be recognized, and informative morphological features to differentiate them from another one are missing (Massana and Pedros-Alio 2008). Flow cytometry presents another methodological approach, which is suited to assess protist size composition but provides no taxonomical information for eukaryotes.

Consequently, including the smallest planktonic fraction in protist studies requires the use of size independent molecular methods, like ARISA or 454pyrosequencing. The present work is one of the first studies that took advantage of molecular methods to analyze the whole size range of protists (micro-, nano-, and picoplankton) in a single approach in the hydrodynamic zone of the Western Fram Strait. Previous studies focused on one size fraction, but an integrated analysis of all three size fractions in parallel was never done. A previous multivariate study, on the late summer composition of picoeukaryotic algae, reported a dominance of chlorophytes in Arctic and of haptophytes in AWs, respectively (Not et al. 2005). The investigated transect passed through the confluence zone of the EGC and the WSC. Hence, the study area comprised both Polar and AW and was characterized by a dynamic sea ice condition.

Our five stations were selected based on the ARISA results and characteristic environmental factors. It has to be mentioned that the selected sampling sites and depths just covered snap-shots of diverse environmental conditions (ice coverage, ice melt, salinity, and temperature), which certainly cannot be sufficient to represent the protist community structure of the whole water masses, due to the inherent patchy distribution of these organisms. Of the five selected stations, two stations displayed higher salinities, showing total (T6) and no ice coverage (T9), and three stations displayed lower salinities, showing moderate ice coverages (T1, T5, and T7). Based on the temperature/salinity profile and the clustering of the different community structures (ARISA), we assign T1 to the PW (EGC), T9 to the AW (WSC), and T5, T6, and T7 to the mixing zone of both water masses. Within the mixing zone, T5 and $\mathrm{T} 7$ were more influenced by the PW, while T6 was more influenced by the AW, due to the deeper 
sampling depth. Overall, the results of the ARISA analyses suggest that the protist community structure in the Fram Strait is determined by the different water masses.

Water samples from $\mathrm{T} 1, \mathrm{~T} 5$, and $\mathrm{T} 7$ were all located in the upper water layer $(15 \mathrm{~m})$. Since the ice condition can highly influence the biomass and the diversity of protists, a survey of the previous ice situation (4 weeks) was done with satellite images, retrieved by MODIS data (Spreen et al. 2008). These satellite images showed a pack-ice tongue that had shifted over the geographical position of $\mathrm{T} 5$. Until then, T5 had been ice-free for at least 6 weeks, while T1 and T7 showed high ice coverages that recently had started to melt. Chlorophyll $a$ concentration, that also derived from the MODIS data, concur with our biomass measurements, and showed at all five stations low Chl $a$ concentrations, suggesting no bloom event during the sampling period.

Stations $\mathrm{T} 1$ and $\mathrm{T} 7$ were dominated by centric diatoms (bacillariophytes) that grouped into the genera Thalassiosira and Porosira, and by a pennate diatom of the genus Fragilariopsis. All three genera have been previously reported in that area during main biomass increase (Booth and Smith 1997, vonQuillfeldt 1997). The similar abundant species composition at $\mathrm{T} 1$ and $\mathrm{T} 7$ is likely to be caused by the ongoing ice melt at both stations. In this respect, the ice may constitute a possible source of the abundant protists assemblage by releasing protist cells into the water column, as first reported by Garrison et al. (1987), where the formation of a stabilizing melt water lens further facilitated the cells to persist for a longer period in the light exposed water surface. The low chlorophyll $a$ concentrations over the previous months at T1, T7, and $\mathrm{T} 5$, however, suggest a deficit in nutrient supply that finally prevents the development of a phytoplankton bloom. Another aspect, explaining the similar community structure at $\mathrm{T} 1$ and $\mathrm{T} 7$, might be the initial stock of protists, where a similar source-population could have been prevalent at both stations. This would strengthen our hypothesis of a stronger PW influence at station T7. In fact, water masses were previously reported to be associated with the distribution of protist and even bacterial assemblages (Lovejoy et al. 2002, Galand et al. 2009).

The third station (T5), located in the mixing zone, displayed a different community that was dominated by dinoflagellates and contrasts with the previous PW (T1) and the PW-influenced (T7) stations. As previously discussed, 454-pyrosequencing might overestimate the dinoflagellates relative abundance in certain species assemblages. Consequently, dinoflagellates could be less abundant at T5, but still dominant. The high abundance of dinoflagellates, however, can also have an ecological background. The most abundant phylotypes encountered in this study were Dinophyceae 1, Woloszynskia sp., and Gyrodinium sp. (dinophytes). In particular, Gyrodinium sp. is reported to be a major consumer of bloom-forming diatoms and can graze down a microphytoplankton bloom within a timeframe of 7-8 days, while it also has the ability to persist outside diatom blooms (Saito et al. 2006, Sherr and Sherr 2007). Hence, the presence of heterotrophic dinoflagellates, as active phytoplankton grazers, constitutes a good indicator for postbloom events (Strom and Strom 1996, Levinsen et al. 2000, Poulsen and Reuss 2002). In this study, the data of the remote sensing observations do not support a previous bloom event at T5. However, it is likely that the ice retreat has caused an increase in diatom abundance, as observed at $\mathrm{T} 1$ and $\mathrm{T} 7$, which in turn promoted a subsequent increase in dinoflagellate proportion. Based on the high abundance of dinoflagellates, we thus assume a scenario of an advanced protist succession at $\mathrm{T} 5$, where diatoms have already been grazed or sunk into deeper water layers. In retrospect, the ice conditions at T5, including the preceding ice-free period, support our assumption. In this study, the ice concentration showed a high influence on the protist community structure at all PW-influenced stations. Although, the simple analysis of the protist diversity (ARISA) pointed to a simple water mass associated distribution, the inclusion of relative abundances (454-pyrosequencing) reflected temporal dynamics, which were affected by the local sea ice conditions. Beyond any doubt, the classification of abundant diatom or dinoflagellate sequences to the genus level was beneficial for these ecological interpretations.

The benefit for ecological interpretation was also observed at station $\mathrm{T} 6$ and T9, located in the mixed water (AW influenced) and in the AW of the WSC, respectively. Even though T6 was ice covered, while T9 was not ice covered at all, both stations presented a similar protist community, independent of sea ice concentration and very different from the ones previously discussed and affected by the PW. In the warmer, more saline water, picoeukaryotes such as Micromonas spp. and Bathycoccus sp. were particularly abundant. The most abundant phylotype, Micromonas sp. 1 assigned to a Micromonas strain (CCMP 2099) already sampled in the Baffin Bay (Slapeta et al. 2006) and in the North Water Polynya (Lovejoy et al. 2007). Those studies identified five Micromonas clades (A-E), in which one (Ea) included exclusively Arctic phylotypes (Slapeta et al. 2006, Lovejoy et al. 2007). Micromonas sp. 1 is part of the arctic Ea clade, that contains strains of Micromonas sp. that grow faster under low light and low temperature (Lovejoy et al. 2007). The other abundant strain, Micromonas sp. 2, could not be assigned in detail, but resembled more the residual clades $\mathrm{A}-\mathrm{C}$ that contain strains with worldwide distributions (Slapeta et al. 2006). This finding might be an indication of AW inflow. Ciliates were 
another dominant group at T6 and T9, showing higher diversity in T9. This group has a wide food spectrum, which can include small as well as larger diatom cells; however, higher abundances of ciliates were reported in the presence of small-celled protists and in the open ocean (Hansen 1991, Nielsen and Kiorboe 1994, Aberle et al. 2007). Data of the remote sensing observations indicate a previous bloom event in June at both stations, 1 month before sampling. Therefore, we assume that one explanation for the high abundance of picoeukaryotes and ciliates at T6 and T9 might be a prevailing post-bloom scenario. Although we cannot make any statements on the prevalent nutrient conditions, which would finally approve the post-bloom stage, we can refer to previous studies that analyzed the local nutrient situation. These studies observed low and almost depleted nitrate concentrations in late summer, apart from a limited protist biomass (Lara et al. 1994, Pesant et al. 1996, Booth and Smith 1997, Kattner and Budeus 1997). This supports our hypothesis of the post-bloom stage at T6 and T9, and points to a shift from a productive to a regenerative system, which is composed of regenerated nutrients and mainly characterized by small size protists, and an active microbial loop (Cushing 1989, Landry et al. 1997, Falkowski et al. 1998). In this scenario, the protist communities of both stations were most probably transported by the recirculating West Spitzbergen Current and no community structure differences were observed at T6 (mixing zone) as a consequence of the high ice concentration which further constrained the autotrophic biomass. Again, the inclusion of protist relative abundances in the diversity study (454-pyrosequencing) was advantageous for the interpretation because ARISA grouped the community structures in different water mass associated clusters.

In summary, the protist distribution observed in the PW-influenced region of the transect could be particularly related to the previous and the prevailing ice coverage that influenced the light availability and hence the timing of protist succession. In the course, protist community in long-light exposed areas was mainly composed of dinoflagellates, while diatoms dominated in areas with ongoing sea ice melt. Picoeukaryotes (Micromonas) relative abundance did not respond to the sea ice situation and showed high contributions in highly ice covered and in open ocean areas, where they characterized the regenerative system. These findings suggest a high relevance to continue studying the impact of sea ice (light availability) on protist community structures, because of the strong temporal controlling effect. However, water masses, characterized by salinity and temperature, further influenced the community structure, and supported a high abundance of small cells (Micromonas and Bathycoccus) in the warm and saline AW or AW influenced station. This observation further demand more studies on the influence of AW on the protist communities in the Western Fram Strait, because of the ongoing warming of the WSC (Schauer et al. 2004, Beszczynska-Möller et al. 2012).

In conclusion, our data present the first molecular-based overview (status quo) of protist diversity in the Western Fram Strait that can contribute to establish baseline information to which future data sets in this region can be compared. In this study, we observed that the sea ice concentration particularly affected protist communities at PW-influenced stations, while higher temperature and salinity positively affected the relative abundance of picoeukaryotes in AW influenced stations. Our observations in combination with predictions of sea ice decline and increasing water temperatures in the Arctic suggest that small picoeukaryotic cells might become more abundant and further distributed in the WSC, if abiotic conditions in the Arctic Ocean become more favorable for them. This hypothesis is in agreement with other studies that predicted an increase of smaller cells in the presence of higher water temperatures ( $\mathrm{Li}$ et al. 2009). In comparison with HPLC, 454-pyrosequencing proved to be a valuable and appropriate tool for retrieving protist community structure shifts and temporal dynamics, including all size fractions in a highly dynamic system like the Western Fram Strait. Nevertheless, it must be mentioned that the picture of protist community structure in this study just presents a snap-shot in a very dynamic region and that no statement concerning changes in protist seasonality, e.g., the influence of earlier ice melt on the timing of phytoplankton blooms, could be made. Therefore, we suggest investigations on a regular basis of the entire protist community structure, including seasonal sampling in dynamic and less dynamic regions, e.g., based on the deployment of sediment traps.

This study was accomplished within the Young Investigator Group PLANKTOSENS (VH-NG-500), funded by the Initiative and Networking Fund of the Helmholtz Association. Further, we thank the captain and crew of the RV Polarstern for their support during the cruises ARKXXV/2. We are especially indebted to S. Frickenhaus, F. Kilpert, and B. Beszteri for their bioinformatical support and very grateful to A. Schroer, A. Nicolaus, K. Oetjen, S. Murawski, and C. Lorenzen for excellent technical support in the laboratory. We also acknowledge the MODIS mission scientists and associated NASA personnel for the production of the data used in this study.

Aberle, N., Lengfellner, K. \& Sommer, U. 2007. Spring bloom succession, grazing impact and herbivore selectivity of ciliate communities in response to winter warming. Oecologia 150:668-81.

Acker, J. G. \& Leptoukh, G. 2007. Online analysis enhances use of NASA Earth Science Data. Eos. Trans AGU 88:14.

Atkinson, D., Ciotti, B. J. \& Montagnes, D. J. S. 2003. Protists decrease in size linearly with temperature: ca. $2.5 \%$ degrees C-1. Proc. R Soc. B Biol. Sci. 270:2605-11.

Barlow, R. G., Cummings, D. G. \& Gibb, S. W. 1997. Improved resolution of mono- and divinyl chlorophylls $a$ and $b$ and zea- 
xanthin and lutein in phytoplankton extracts using reverse phase C-8 HPLC. Mar. Ecol. Prog. Ser. 161:303-7.

Beszczynska-Möller, A., Fahrbach, E., Schauer, U. \& Hansen, E. 2012. Variability in atlantic water temperature and transport at the entrance to the arctic ocean, 1997-2010. ICES J. Mar. Sci. 69:852-63.

Bidigare, R. R. 1991. Analysis of algal chlorophylls and carotenoids. In Hurd, D. C. \& Spencer, D. W. [Eds.] Geophysical Monographs Series. American Geophysical Union, Washington, D.C., pp. 119-23.

Bjørnland, T. \& Liaaen-Jensen, S. 1989. Distribution patterns of carotenoids in relation to chromophyte phylogeny and systematics. In Green, J. C., Leadbeater, B. S. C. \& Diver, W. L. [Eds.] The Chromophyte Algae: Problems and Perspectives. Systematics Association Special Vol. 38: 37-60.

Booth, B. C. \& Horner, R. A. 1997. Microalgae on the Arctic Ocean Section, 1994: species abundance and biomass. DeepSea Res. Part II-Top Stud. Oceanogr. 44:1607-22.

Booth, B. C. \& Smith, W. O. 1997. Autotrophic flagellates and diatoms in the Northeast Water Polynya, Greenland: summer 1993. J. Mar. Syst. 10:241-61.

Bopp, L., Aumont, O., Cadule, P., Alvain, S. \& Gehlen, M. 2005. Response of diatoms distribution to global warming and potential implications: a global model study. Geophys. Res. Lett. 32. doi:10.1029/2005GL023653.

Cheung, M. K., Au, C. H., Chu, K. H., Kwan, H. S. \& Wong, C. K. 2010. Composition and genetic diversity of picoeukaryotes in subtropical coastal waters as revealed by 454 pyrosequencing. ISME J. 4:1053-9.

Cotterill, F. P. D., Al-Rasheid, K. A. S. \& Foissner, W. 2008. Conservation of protists: is it needed at all? Biodivers. Conserv. $17: 427-43$.

Courties, C., Vaquer, A., Troussellier, M., Lautier, J., Chretiennotdinet, M. J., Neveux, J., Machado, C. \& Claustre, H. 1994. Smallest eukaryotic organism. Nature 370:255-255.

Cushing, D. H. 1989. A difference in structure between ecosystems in strongly stratified waters and in those that are only weakly stratified. J. Plankton Res. 11:1-13.

Danovaro, R., Luna, G. M., Dell'anno, A. \& Pietrangeli, B. 2006. Comparison of two fingerprinting techniques, terminal restriction fragment length polymorphism and automated ribosomal intergenic spacer analysis, for determination of bacterial diversity in aquatic environments. Appl. Environ. Microbiol. 72:5982-9.

Daufresne, M., Lengfellner, K. \& Sommer, U. 2009. Global warming benefits the small in aquatic ecosystems. Proc. Natl. Acad. Sci. U.S.A. 106:12788-93.

Diez, B., Pedros-Alio, C. \& Massana, R. 2001. Study of genetic diversity of eukaryotic picoplankton in different oceanic regions by small-subunit rRNA gene cloning and sequencing. Appl. Environ. Microbiol. 67:2932-41.

Dray, S. \& Dufour, A. B. 2007. The ade4 package: implementing the duality diagram for ecologists. J. Stat. Softw. 22:1-20.

Edgar, R. C., Haas, B. J., Clemente, J. C., Quince, C. \& Knight, R. 2011. UCHIME improves sensitivity and speed of chimera detection. Bioinformatics 27:2194-200.

Edler, L. 1979. Recommendations on methods for marine biological studies in the Baltic Sea. Phytoplankton and chlorophyll. BMB Publ. 5:1-38.

Elwood, H. J., Olsen, G. J. \& Sogin, M. L. 1985. The small-subunit ribosomal-RNA gene sequences from the hypotrichous ciliates Oxytrichia nova and Stylonychia pustulata. Mol. Biol. Evol. 2:399-410.

Evans, C. A. \& O'Reily, J. E. 1987. A handbook for the measurement of chlorophyll $a$ in netplankton and nanoplankton. BIOMASS Handbook 9:1-14.

Falkowski, P. G., Barber, R. T. \& Smetacek, V. 1998. Biogeochemical controls and feedbacks on ocean primary production. Science 281:200-6.

Fields, S. D. \& Rhodes, R. G. 1991. Ingestion and retention of Chroomonas spp. (Cryptophyceae) by Gymnodinium acidotum (Dinophyceae). J. Phycol. 27:525-9.
Flynn, K. J., Stoecker, D. K., Mitra, A., Raven, J. A., Glibert, P. M., Hansen, P. J., Graneli, E. \& Burkholder, J. M. 2013. Misuse of the phytoplanktonzooplankton dichotomy: the need to assign organisms as mixotrophs within plankton functional types. J. Plankton Res. 35:3-11.

Foissner, W., Berger, H. \& Schaumburg, J. 1999. Identification and ecology of limnetic plankton ciliates. Informationsberichte des Bayerischen Landesamtes fuer Wasserwirtschaft 3:1-793.

Galand, P. E., Casamayor, E. O., Kirchman, D. L. \& Lovejoy, C. 2009. Ecology of the rare microbial biosphere of the Arctic Ocean. Proc. Natl. Acad Sci. U.S.A. 106:22427-32.

Garrison, D. L., Buck, K. R. \& Fryxell, G. A. 1987. Algal assemblages in Antarctic pack ice and in ice edge plankton. J. Phycol. 23:564-72.

Gonzalez, J. M., Sherr, B. F. \& Sherr, E. B. 1993. Digestive enzyme activity as a quantitative measure of protistan grazing: The acid lysozyme assay for bacterivory. Mar. Ecol. Prog. Ser. 100:197-206.

Hamilton, A. K., Lovejoy, C., Galand, P. E. \& Ingram, R. G. 2008. Water masses and biogeography of picoeukaryote assemblages in a cold hydrographically complex system. Limnol. Oceanogr. 53:922-35.

Hansen, P. J. 1991. Quantitative importance and trophic role of heterotrophic dinoflagellates in a coastal pelagial food web. Mar. Ecol. Prog. Ser. 73:253-61.

Hegseth, E. N. \& Sundfjord, A. 2008. Intrusion and blooming of Atlantic phytoplankton species in the high Arctic. J. Mar. Syst. 74:108-19.

Higgins, M. B., Wolfe-Simon, F., Robinson, R. S., Qin, Y. L., Saito, M. A. \& Pearson, A. 2011. Paleoenvironmental implications of taxonomic variation among delta $\mathrm{N}-15$ values of chloropigments. Geochim. Cosmochim. Acta 75:7351-63.

IPCC, Intergovernmental Panel on Climate Change. Working Group I 2007. Climate Change 2007: The Physical Science Basis: Contribution of Working Group I to the Fourth Assessment Report of the Intergovernmental Panel on Climate Change. Cambridge University Press, New York, 996 pp.

Irigoien, X., Meyer, B., Harris, R. \& Harbour, D. 2004. Using HPLC pigment analysis to investigate phytoplankton taxonomy: the importance of knowing your species. Helgoland Mar. Res. 58:77-82.

Jeffrey, S. W., Sielicki, M. \& Haxo, F. T. 1975. Chloroplast pigment patterns in dinoflagellates. J. Phycol. 11:374-84.

Jeffrey, S. W., Vesk, M. \& Mantoura, R. F. C. 1997. Phytoplankton pigments: windows into the pastures of the sea. Nat. Resour. 33:14-29.

Kahru, M., Brotas, V., Manzano-Sarabia, M. \& Mitchell, B. G 2011. Are phytoplankton blooms occurring earlier in the Arctic? Glob. Change Biol. 17:1733-9.

Kattner, G. \& Budeus, G. 1997. Nutrient status of the Northeast Water Polynya. J. Mar. Syst. 10:185-97.

Kunin, V., Engelbrektson, A., Ochman, H. \& Hugenholtz, P. 2010. Wrinkles in the rare biosphere: pyrosequencing errors can lead to artificial inflation of diversity estimates. Environ. Microbiol. 12:118-23.

Landry, M. R., Barber, R. T., Bidigare, R. R., Chai, F., Coale, K. H., Dam, H. G., Lewis, M. R. et al. 1997. Iron and grazing constraints on primary production in the central equatorial Pacific: an EqPac synthesis. Limnol. Oceanogr. 42:405-18.

Lara, F. J., Kattner, G., Tillmann, U. \& Hirche, H. J. 1994. The north-east water polynya (Greenland Sea). 2. Mechanisms of nutrient supply and influence of phytoplankton distribution. Polar Biol. 14:483-90.

Legendre, L. \& Le Fèvre, J. 1991. From Individual Plankton Cells to Pelaglc Marine Ecosystems and to Global Biogeochemical Cycles. Springer-Verlag, Berlin, pp. 261-99.

Levinsen, H., Turner, J. T., Nielsen, T. G. \& Hansen, B. W. 2000. On the trophic coupling between protists and copepods in arctic marine ecosystems. Mar. Ecol. Prog. Ser. 204:65-77.

Li, W. K. W., Mclaughlin, F. A., Lovejoy, C. \& Carmack, E. C. 2009. Smallest algae thrive as the arctic ocean freshens. Science 326:539. 
Liu, H., Probert, I., Uitz, J., Claustre, H., Aris-Brosou, S., Frada, M., Not, F. \& de Vargas, C. 2009. Extreme diversity in noncalcifying haptophytes explains a major pigment paradox in open oceans. Proc. Natl. Acad. Sci. U.S.A. 106:12803-8.

Lopez-Garcia, P., Lopez-Lopez, A., Moreira, D. \& Rodriguez-Valera, F. 2001. Diversity of free-living prokaryotes from a deep-sea site at the Antarctic Polar Front. FEMS Microbiol. Ecol. 36:193-202.

Lovejoy, C., Legendre, L., Martineau, M. J., Bacle, J. \& von Quillfeldt, C. H. 2002. Distribution of phytoplankton and other protists in the North Water. Deep-Sea Res. Part II-Top Stud. Oceanogr. 49:5027-47.

Lovejoy, C., Massana, R. \& Pedros-Alio, C. 2006. Diversity and distribution of marine microbial eukaryotes in the Arctic Ocean and adjacent seas. Appl. Environ. Microbiol. 72:3085-95.

Lovejoy, C., Vincent, W. F., Bonilla, S., Roy, S., Martineau, M. J., Terrado, R., Potvin, M., Massana, R. \& Pedros-Alio, C. 2007. Distribution, phylogeny, and growth of cold-adapted picoprasinophytes in arctic seas. J. Phycol. 43:78-89.

Ludwig, W., Strunk, O., Westram, R., Richter, L., Meier, H., Yadhukumar, Buchner, A. et al. 2004. ARB: a software environment for sequence data. Nucleic Acids Res. 32:1363-71.

Mackey, M. D., Mackey, D. J., Higgins, H. W. \& Wright, S. W. 1996. CHEMTAX - A program for estimating class abundances from chemical markers: application to HPLC measurements of phytoplankton. Mar. Ecol. Prog. Ser. 144:265-83.

Margulies, M., Egholm, M., Altman, W. E., Attiya, S., Bader, J. S., Bemben, L. A., Berka, J. et al. 2005. Genome sequencing in microfabricated high-density picolitre reactors. Nature 437:376-80.

Massana, R. \& Pedros-Alio, C. 2008. Unveiling new microbial eukaryotes in the surface ocean. Curr. Opin. Microbiol. $11: 213-8$.

Matsen, F. A., Kodner, R. B. \& Armbrust, E. V. 2010. pplacer: linear time maximum-likelihood and Bayesian phylogenetic placement of sequences onto a fixed reference tree. $B M C$ Bioinformatics 11. doi:10.1186/1471-2105-11-538.

Medlin, L., Elwood, H. J., Stickel, S. \& Sogin, M. L. 1988. The characterization ofenzymatically amplified eukaryotic 16S-like rRNA-coding regions. Gene 71:491-9.

Medlin, L. K., Metfies, K., Mehl, H., Wiltshire, K. \& Valentin, K. 2006. Picoeukaryotic plankton diversity at the Helgoland time series site as assessed by three molecular methods. Microbial Ecol. 52:53-71.

Moon-van der Staay, S. Y., De Wachter, R. \& Vaulot, D. 2001. Oceanic 18S rDNA sequences from picoplankton reveal unsuspected eukaryotic diversity. Nature 409:607-10.

Moran, X. A. G., Lopez-Urrutia, A., Calvo-Diaz, A. \& Li, W. K. W. 2010. Increasing importance of small phytoplankton in a warmer ocean. Glob. Change Biol. 16:1137-44.

Moran, S. B., Lomas, M. W., Kelly, R. P., Gradinger, R., Iken, K. \& Mathis, J. T. 2012. Seasonal succession of net primary productivity, particulate organic carbon export, and autotrophic community composition in the eastern Bering Sea. Deep-Sea Res PT II 65-70:84-97.

Nickrent, D. L. \& Sargent, M. L. 1991. An overview of the secondary structure of the V4-region of eukaryotic small-subunit ribosomal-RNA. Nucleic Acids Res. 19:227-35.

Nielsen, T. G. \& Kiorboe, T. 1994. Regulation of zooplankton biomass and production in a temperate, coastal ecosystem. 2. Ciliates. Limnol. Oceanogr. 39:508-19.

Not, F., Latasa, M., Scharek, R., Viprey, M., Karleskind, P., Balague, V., Ontoria-Oviedo, I., Cumino, A., Goetze, E., Vaulot, D. \& Massana, R. 2008. Protistan assemblages across the Indian Ocean, with a specific emphasis on the picoeukaryotes. Deep Sea Res. Part I Oceanogr. Res. Pap. 55:1456-73.

Not, F., Massana, R., Latasa, M., Marie, D., Colson, C., Eikrem, W., Pedros-Alio, C., Vaulot, D. \& Simon, N. 2005. Late summer community composition and abundance of photosynthetic picoeukaryotes in Norwegian and Barents Seas. Limnol. Oceanogr. 50:1677-86.
Oksanen, J., Blanchet, F. G., Kindt, R., Legendre, P., O'Hara, R. B., Simpson, G. L., Solymos, P., Stevens, M. H. H. \& Wagner, H. 2011. Vegan: Community Ecology Package. Available at: http://cran.r-project.org ( $\mathrm{R}$ package version 1.17-6).

Pesant, S., Legendre, L., Gosselin, M., Smith, R. E. H., Kattner, G. \& Ramseier, R. O. 1996. Size-differential regimes of phytoplankton production in the northeast water Polynya (77 degrees-81 degrees N). Mar. Ecol. Prog. Ser. 142:75-86.

Peter, K. H. \& Sommer, U. 2012. Phytoplankton cell size: intraand interspecific effects of warming and grazing. PLoS ONE 7:e49632.

Poulsen, L. K. \& Reuss, N. 2002. The plankton community on Sukkertop and Fylla Banks off West Greenland during a spring bloom and post-bloom period: hydrography, phytoplankton and protozooplankton. Ophelia 56:69-85.

Pruesse, E., Quast, C., Knittel, K., Fuchs, B. M., Ludwig, W. G., Peplies, J. \& Glockner, F. O. 2007. SILVA: a comprehensive online resource for quality checked and aligned ribosomal RNA sequence data compatible with ARB. Nucleic Acids Res. 35:7188-96.

von Quillfeldt, C. H. 1997. Distribution of diatoms in the Northeast Water Polynya. Greenland. J. Mar. Syst. 10:211-40.

R Development Core Team, 2008. R-A Language and Environment for Statistical Computing. R Foundation for Statistical Computing, Vienna. Available at: http://www.R-project.org.

Ramette, A. 2009. Quantitative community fingerprinting methods for estimating the abundance of operational taxonomic units in natural microbial communities. Appl. Environ. Microbiol. 75:2495-505.

Rudels, B., Bjork, G., Nilsson, J., Winsor, P., Lake, I. \& Nohr, C. 2005. The interaction between waters from the Arctic Ocean and the Nordic Seas north of Fram Strait and along the East Greenland Current: results from the Arctic Ocean-02 Oden expedition. J. Mar. Syst. 55:1-30.

Saito, H., Ota, T., Suzuki, K., Nishioka, J. \& Tsuda, A. 2006. Role of heterotrophic dinoflagellate Gyrodinium sp. in the fate of an iron induced diatom bloom. Geophys. Res. Lett. 33. doi: 10.1029/2005GL025366.

Schauer, U., Fahrbach, E., Osterhus, S. \& Rohardt, G. 2004. Arctic warming through the fram strait: oceanic heat transport from 3 years of measurements. J. Geophys. Res. Oceans, 109. doi: 10.1029/2003JC001823.

Sherr, E. B. \& Sherr, B. F. 2007. Heterotrophic dinoilagellates: a significant component of microzooplankton biomass and major grazers of diatoms in the sea. Mar. Ecol. Prog. Ser. 352:187-97.

Skovgaard, A. 1998. Role of chloroplast retention in a marine dinoflagellate. Aquat. Microb. Ecol. 15:293-301.

Slapeta, J., Lopez-Garcia, P. \& Moreira, D. 2006. Global dispersal and ancient cryptic species in the smallest marine eukaryotes. Mol. Biol. Evol. 23:23-9.

Smith, J. L., Barrett, J. E., Tusnady, G., Rejto, L. \& Cary, S. C. 2010. Resolving environmental drivers of microbial community structure in Antarctic soils. Antarctic Sci. 22:673-80.

Sogin, M. L., Morrison, H. G., Huber, J. A., Mark Welch, D., Huse, S. M., Neal, P. R., Arrieta, J. M. \& Herndl, G. J. 2006. Microbial diversity in the deep sea and the underexplored "rare biosphere". Proc. Natl. Acad. Sci. U.S.A. 103:12115-20.

Spreen, G., Kaleschke, L. \& Heygster, G. 2008. Sea ice remote sensing using AMSR-E 89-GHz channels. J. Geophys. Res. Oceans 113. doi:10.1029/2005JC003384.

Stoeck, T., Bass, D., Nebel, M., Christen, R., Jones, M. D. M., Breiner, H. W. \& Richards, T. A. 2010. Multiple marker parallel tag environmental DNA sequencing reveals a highly complex eukaryotic community in marine anoxic water. Mol. Ecol. 19:21-31.

Stoecker, D. K., Johnson, M. D., de Vargas, C. \& Not, F. 2009. Acquired phototrophy in aquatic protists. Aquat. Microb. Ecol. 57:279-310.

Strom, S. L. \& Strom, M. W. 1996. Microplankton growth, grazing, and community structure in the northern Gulf of Mexico. Mar. Ecol. Prog. Ser. 130:229-40. 
Tremblay, J. E., Michel, C., Hobson, K. A., Gosselin, M. \& Price, N. M. 2006. Bloom dynamics in early opening waters of the Arctic Ocean. Limnol. Oceanogr. 51:900-12.

Vaulot, D., Eikrem, W., Viprey, M. \& Moreau, H. 2008. The diversity of small eukaryotic phytoplankton $(\leq 3 \mu \mathrm{m})$ in marine ecosystems. FEMS Microbiol. Rev. 32:795-820.

Wassmann, P., Duarte, C. M., Agusti, S. \& Sejr, M. K. 2011. Footprints of climate change in the Arctic marine ecosystem. Glob. Change Biol. 17:1235-49.

Watanabe, M. M., Suda, S., Inouye, I., Sawaguchi, T. \& Chihara, M. 1990. Lepidodinium viride gen et sp.-nov (Gymnodiniales, Dinophyta), a green dinoflagellate with a chlorophyll $a$-containing and $b$-containing endosymbiont. J. Phycol. 26:741-51.

Watanabe, M. M., Takeda, Y., Sasa, T., Inouye, I., Suda, S., Sawaguchi, T. \& Chihara, M. 1987. A green dinoflagellate with chlorophyll $a$ and chlorophyll $b$ : Morphology, fine-structure of the chloroplast and chlorophyll composition. J. Phycol. 23:382-9.

White, T. J., Bruns, T., Lee, S. \& Taylor, J.W. 1990. Amplification and direct sequencing of fungal ribosomal RNA genes for phylogenetics. In Innis, M. A., Gelfand, D. H., Sninsky, J. J. \& White, T. J. [Eds.] PCR Protocols: A Guide to Methods and Applications. Academic Press, San Diego, CA, pp. 315-22.

Wolf, C., Frickenhaus, S., Kilias, E. S., Peeken, I. \& Metfies, K. 2013. Regional variability in eukaryotic protist communities in the Amundsen Sea. Antarct. Sci.. doi:10.1017/ S0954102013000229.

Wright, S. W., Jeffrey, S. W., Mantoura, R. F. C., Llewellyn, C. A., Bjornland, T., Repeta, D. \& Welschmeyer, N. 1991. Improved HPLC method for the analysis of chlorophylls and carotenoids from marine phytoplankton. Mar. Ecol. Prog. Ser. 77:183-96.

Zhu, F., Massana, R., Not, F., Marie, D. \& Vaulot, D. 2005. Mapping of picoeucaryotes in marine ecosystems with quantitative PCR of the 18S rRNA gene. FEMS Microbiol. Ecol. 52:79-92.

\section{Supporting Information}

Additional Supporting Information may be found in the online version of this article at the publisher's web site:

Fig. S1. Seasonal development of area-averaged chlorophyll $a$ concentration at, obtained by remote sensing observations. Two different areas have been selected: $12^{\circ} \mathrm{W}-4^{\circ} \mathrm{W}, 78^{\circ} \mathrm{N}-80^{\circ} \mathrm{N}$, solid line, representing the stations $\mathrm{T} 1, \mathrm{~T} 5, \mathrm{~T} 7$, and $5^{\circ} \mathrm{W}-0^{\circ} \mathrm{E}, 78^{\circ} \mathrm{N}-80^{\circ} \mathrm{N}$, scattered line, representing $\mathrm{T} 6$ and $\mathrm{T} 9$, respectively. The period of our investigation is enclosed by the square (18-23 July). Concentrations are derived from MODIS data.

Table S1. Coordinates, chlorophyll $a$ and ice content of surface water samples along the transect.

Table S2. 454-pyrosequencing - OTU read distribution. 